\title{
The Relationship between Body Composition and Jumping Performance of Volleyball Players
}

\author{
Hakan Acar ${ }^{1}$, Nebahat Eler ${ }^{1}$ \\ ${ }^{1}$ Department of Physical Education and Sport, Zonguldak Bülent Ecevit University, Zonguldak, Turkey \\ Correspondence: Nebahat Eler Department of Physical Education and Sport, Zonguldak Bülent Ecevit University, \\ Zonguldak, Turkey.
}

Received: February 14, 2019

Accepted: February 23, 2019

Online Published: February 26, 2019

doi:10.11114/jets.v7i3.4047

URL: https://doi.org/10.11114/jets.v7i3.4047

\begin{abstract}
Body composition and the skill of jumping are very important for high physical performance in volleyball. The purpose of this study is to analyze the relationship between body composition and jumping performance in female volleyball players aged 14-17. 74 female volleyball players volunteered to participate in the study. The height, body weight, body mass index, body fat percentage, body muscle mass and trunk fat percentage measurements were taken and the vertical jump and standing long jump tests were applied. The data were evaluated with the SPSS 16 statistical software program, the Pearson Correlation test was done for the statistical analysis and the significance level was determined as $\mathrm{p}<0.05$. The athletes' vertical jump and standing long jump values were found statistically to have a negative relationship with height, body fat percentage, body muscle mass and body fat percentage, whereas a positive relationship was found between vertical jump and standing long jump values and body weight $(\mathrm{p}<0.05)$. As a result, it was determined that body composition in volleyball players affects jumping performance.
\end{abstract}

Keywords: jumping performance, body composition, volleyball

\section{Introduction}

There is clear scientific evidence of a strong relationship between morphological characteristics and the chosen sport (Eston \& Reilly, 2009). Depending on the athletes' sports branch, their physical conditions, body compositions and technical tactic capacities affect their performance (Aytek, 2007). Each sports branch has its own needs and each athlete should have unique anthropometrical characteristic and a body composition for his/her own sports discipline (Massuça \& Fragoso, 2011). There are numerous body composition components in sports. For instance, height, weight, body fat, fat free mass, muscle mass, total body water, etc. However, the most important components in all sports branches is body fat because each characteristic has a great relationship with body fat such as agility, power, speed, flexibility, explosive power and jumping skills (Aytek, 2007).

Volleyball is a sports branch which requires advanced physical fitness and anthropometrical characteristics (Göral et al., 2009). Volleyball is a sport in which the most prominent body characteristic, besides physical abilities such as agility, reaction speed, movement speed, or aerobic and alactic power, is longitudinality (Palao et al., 2014).

In general, volleyball players have a body height which is higher than average, a thin shape, endurance, power and the skill of jumping ( Malousaris et al., 2008; Carvajal et al., 2012 ). The anthropometrical characteristics and jumping skill of volleyball players are the most important factors in the success of their team in terms of performance (Clarke, 1975). Besides high technical and tactical skills, suitable anthropometrical characteristics and body composition is need in volleyball. It has been determined that, being successful in the volleyball branch is directly related to power (vertical jump) which is one of the basic motor functions, speed, flexibility and low body fat percentage ( Şimşek et al., 2007; Ivanović, 2009; Koç et al., 2010; Con et al., 2012 ).

In block and spike movements, jumping too high is important in the success. Jumping power is defined as the athlete's jumping as much as possible from far from the vertical and/or jumping high in the vertical position. As for the jumping movement, it is seen that the flexor and extensor muscles in the lower extremity are effective (Şimşek et al., 2007). In volleyball, being tall and having the skill of jumping high are needed for the block and spike movements. Body fat percentage affects the skill of jumping (Aytek, 2007). 
Anthropometrical measurements are important in the estimation of physical and physiological performances. The weight, fat and muscle mass of athletes are important factors which affect in particular jumping performance (Moncef et al., 2012). Anthropometric profiling and physical performance testing, including different approaches to body composition comparisons and somatotyping, have been widely used as talent identification and recruitment tools and training program bases for varying competitive levels in many countries which has led to more internationally - competitive volleyball teams (Valleser et al., 2018). In general, low body fat is preferred for high physical performance in volleyball (Heyward \& Stolorczyk 1996). The most effective criterion in determining performance in sports is body height and body weight. Body height and body weight are among the anthropometrical prerequisites which are needed in the selection athletes and their development (Sevim, 2002; Savaş \& Uğraş 2004). Therefore, it is highly important to deal with body composition and the skill of jumping which are very important in especially volleyball together. The purpose of this study is to analyze the relationship between body composition and jumping performance in female volleyball players aged 14-17.

\section{Method}

Athletes from Ankaragücü, Devlet Hava Limanı Meydanları, Karayolları and Gazi sports clubs among the junior varsity category in the city of Ankara participated voluntarily in the study.

The body height of the athletes was measured with a height scale with $0.01 \mathrm{~mm}$ sensitivity and body composition (Body Mass Index $\left(\mathrm{kg} . \mathrm{m}^{2}\right)$, Body Fat $(\%)$, Body fat percentage $(\%)$, trunk estimated muscle mass $(\mathrm{kg})$ were measured with Tanita (BC - 418) body analysis device.

In the standing long jump test, the athletes jumped forward twice from the starting point on two feet and the longest distance after the jump was recorded as $\mathrm{cm}$.

The vertical jump test was measured with Takei jump meter; it was attached to the abdominal area of the athletes and the athletes were asked to jump vertically on both feet within a certain area and to fall to another area leaving their arms free. This was repeated twice and the highest value was recorded as $\mathrm{cm}$.

In the analysis of the data, the SPSS 16 software was used and the Pearson Correlation test was done $(\mathrm{p}<0.05)$.

\section{Results}

The age average of the participants was determined as $14.8 \pm 1.0$ years, their sports age average as $4.7 \pm 2.1$ years, body height average as $170.3 \pm 6.7 \mathrm{~cm}$ and body weight average as $59.1 \pm 8.3 \mathrm{~kg}$.

Table 1. Some demographical characteristics of the athletes

\begin{tabular}{llll}
\hline & n & Average & SS \\
\hline Age (years) & 74 & 14.8 & 1.0 \\
\hline Body height $(\mathbf{c m})$ & 74 & 170.3 & 6.7 \\
\hline Body weight $(\mathbf{k g})$ & 74 & 59.1 & 8.3 \\
\hline Sports age (years) & 74 & 4.7 & 2.1 \\
\hline
\end{tabular}

Table 2. The measurement values of the participants

\begin{tabular}{llll}
\hline & n & Average & SS \\
\hline Vertical jump $(\mathbf{c m})$ & 74 & 32.5 & 3.9 \\
\hline Standing long jump $(\mathbf{c m})$ & 74 & 174.9 & 17.8 \\
\hline Body Mass Index $\left(\mathbf{k g} . \mathbf{~ m}^{\mathbf{2}}\right)$ & 74 & 20.3 & 2.2 \\
\hline Fat percentage $(\boldsymbol{\%})$ & 74 & 23.6 & 3.8 \\
\hline Trunk fat percentage $(\boldsymbol{\%})$ & 74 & 18.4 & 5.0 \\
\hline Trunk estimated muscle mass $(\mathbf{k g})$ & 74 & 24.9 & 3.0 \\
\hline
\end{tabular}

The vertical jump average of the athletes was determined as $32.5 \pm 3.9 \mathrm{~cm}$ and their standing long jump average as $174.9 \pm 17.8 \mathrm{~cm}$. The body mass index of the participants was determined as $20.3 \pm 2.2 \mathrm{~kg} / \mathrm{m}^{2}$, body fat percentage as $23.6 \pm 3.8 \%$, trunk fat percentage as $18.4 \pm 5.0 \%$ and their trunk estimated muscle mass as $24.9 \pm 3.0 \mathrm{~kg}$.

Table 3. Comparison of the athletes' body composition and jumping performance

\begin{tabular}{|c|c|c|c|c|c|c|c|c|}
\hline & & & Height & Weight & $\begin{array}{l}\text { Body } \\
\text { index }\end{array}$ & Fat $\%$ & $\begin{array}{l}\text { Trunk muscle } \\
\text { mass }\end{array}$ & Trunk fat $\%$ \\
\hline \multirow{2}{*}{$\begin{array}{l}\text { Vertical } \\
(\mathrm{cm})\end{array}$} & \multirow{2}{*}{ jump } & $\mathbf{r}$ & -0.183 & 0.1518 & -0.0575 & -0.2759 & 0.1883 & -0.1927 \\
\hline & & $\mathbf{p}$ & $0.041 *$ & $0.045 *$ & 0.283 & $0.036 *$ & $0.044 *$ & $0.037 *$ \\
\hline \multirow{2}{*}{$\begin{array}{l}\text { Standing } \\
\text { jump }(\mathrm{cm})\end{array}$} & \multirow[t]{2}{*}{ long } & $\mathbf{r}$ & -0.213 & 0.2428 & -0.30783 & -0.4724 & 0.1220 & -0.3349 \\
\hline & & $\bar{p}$ & $0.039 *$ & $0.033 *$ & 0.291 & $0.000 *$ & $0.043 *$ & $0.023 *$ \\
\hline
\end{tabular}

A statistically negative relationship between the athletes' vertical jump and standing long jump values and body height, body fat percentage, trunk muscle mass and trunk fat percentage, whereas a positive relationship was found between their vertical jump and standing long jump values and body weight $(\mathrm{p}<0.05)$. 


\section{Discussion}

As a result of the measurements taken in the presented study, a statistically negative relationship between the athletes' vertical jump and standing long jump values and body height, body fat percentage, trunk muscle mass and trunk fat percentage, whereas a positive relationship was found between their vertical jump and standing long jump values and body weight ( $\mathrm{p}<0.05)$. Aslan et al., (2011) determined a correlation between body weight and standing long jump. Şimşek et al. (2007), in their study in which they analyzed the effect of knee muscle strength on jumping performance, they determined that there is a significant relationship between body weight and jumping performance in 1st league volleyball players. Aouichaoui et al. (2014), in their study on puberty period athletes, determined a negative correlation between vertical jump performance and body weight, height and body mass index. Moncef et al. (2012) determined a negative correlation between body weight and jumping performance in elite male handball players. Almuzaini (2007), stated that there is correlation between body height and body weight and vertical jump. Günay et al. (1994) stated that there is correlation between body weight and strength, vertical jump, flexibility and anaerobic strength.

Białoskórska et al. (2016), determined a significant correlation between the vertical jump skills and body compositions of volleyball players and determined a positive relationship between vertical jump height and all body muscle mass and determined a negative relationship between body fat percentage and body mass index. Silvestre et al. (2006) determined a strong correlation between body composition and vertical jump and Ostojic et al. (2006) determined a strong correlation between body composition and anaerobic strength. Şimşek et al. (2005) determined a negative correlation between body weight and jumping.

Crawford (1996), stated that body measurements play an important role in the performance of humans and people with greater body measurements have more strength and maximum anaerobic strength. Markovic and Jaric (2007) stated in their study involving 159 participants that while body weight affects strength and anaerobic strength in a positive manner, it affects vertical jump height in a negative manner. Copić et al. (2014), in their study on athletes, determined that the higher the body fat percentage, the lower the vertical jump height. Vuleta et al. (2016) stated that the skill of jumping determines the level difference between volleyball players. Nikolaidis (2013) stated that high pat percentages negatively affect the productivity of volleyball players.

In the light of the results in the literature, it can be stated that the skill of jumping and body fat percentage are the most important determinants of performance in volleyball players. Our study supports the current information. In our study, it was determined that body composition affects jumping performance as well. It is quite important for the targeted performance to determine these characteristics in young volleyball players in order to be able to identify and increase their skill at early ages and take precautions and carry out activities to develop their skill. Coaches and trainers who will be working in this area, it will be beneficial to take these measurements at early ages and determine them. Coaches should also do regular follow-up of their athletes and make it possible for measurements to be taken and tests to be conducted in regular intervals in this area.

\section{References}

Almuzaini, S. K. (2007). Muscle function in Saudi children and adolescents: relationship to antropometric characteristics during growth, Pediatric Exercise Science, 19(3), 319-333.

Aouichaoui, C., Trabelsi, Y., Tabka, Z., Dogui, M., Richalet, J., \& Bouhlel, E., (2014). Effect of anthropometric characteristics and socio - economic status on vertical jumping performances in Tunisian athletic children. American Journal of Sports Science and Medicine, 2(1), 6-16. doi:10.12691/ajssm-2-1-2

Aslan, C. S., Büyükdere, C., Köklü, Y., Özkan, A., \& Özdemir, N. Ş. (2011). The relationships among body composition, anaerobic performance and back strength characteristics of sub - elite athletes. Journal of Human Sciences, 8(1), 1613-1628.

Aytek, A. İ. (2007). Body composition of turkish volleyball players. intensive course in biological anthropology 1 st summer school of the european anthropological association. EAA Summer School Ebook, Prague, Czech Republic, 1, 203-208.

Białoskórska, M., Tomczyk, E., Tomczyk, A., \& Szafraniec, R. (2016). Relations between vertical jump height and volleyball players' body composition, Scientific Review Of Physical Culture, 6(1), 56-62.

Carvajal, W., Betancourt, H., León, S., Deturnel, Y., Martínez, M., Echevarría, I., ... Serviat, N. (2012). Kinanthropometric profile of cuban women olympic volleyball champions, Medicc rev., 14(2), 16-22.

Clarke, O. H., (1975). Exercise Physiology. Prentice Hall, New Jersey, USA.

Çon, M., Akyol, P., Tural, E., \& Taşmektepligil, M. Y. (2012). The effect of flexibility and body fat percentage on vertical jump performance with volleyball players, Selçuk University Journal of Physical Education and Sport 
Science, 14(2), 202-207.

Copić, N., Dopsaj, M., Ivanović, J., Nešić, G., \& Jarić, S. (2014). Body composition and muscle strength predictors of jumping performance: differences between elite female volleyball competitors and nontrained individuals, $J$ Strength Cond Res., 28(10), 2709 - 2716. https://doi.org/10.1519/JSC.0000000000000468

Crawford, S. M. (1996). Anthropometry in measurement in pediatric exercise science. Docherty, D. (Ed.) Champaing, IL: Human Kinetics.

Eston, R. G. \& Reilly, T. (Eds.). Kinanthropometry and exercise physiology laborytory manual: tests, procedures and data. Volume 1: Antropometry. New York, Routledge, 2009.

Göral, K., Saygın, Ö., Karacabey, K., \& Gelen, E., (2009). Comparison of some physical fitness parameters of volleybal players and tennis players. $e^{-}$Journal of New World Sciences Academy. 4(3), 227-235. https://doi.org/10.14486/IntJSCS434

Günay, M., Erol, A. E., \& Savaş, S., (1994). The relationship of strength, flexibilitiy and anaerobic power with body height - weight and some anthropometric parameters in soccer players. Hacettepe Üniversitesi Spor Bilimleri Dergisi, 5(4), 3-11.

Heyward, V. H., \& Stolarczyk, L. M., (1996). Applied Body Composition Assessment, Human Kinetics, USA. Norton.

Ivanović, M. (2009). Discriminative analysis of morphological variables between two basketball categories (cadets and seniors). Acta Kinesiologica, 3 (2), 62-66.

Koç, H., \& Aslan, C. S. (2010). The Comparison of male handball and volleyball players' selected physical and motor skills. Selçuk University Journal of Physical Education and Sport Science, 12(3), 227-231.

Malousaris, G. G., Bergeles, N. K., Barzouka, K. G., Bayios, I. A., Nassis, G. P., \& Koskolou, M. D. ( 2008 ). Somatotype, size and body composition of competitive female volleyball players, J Sci Med Sport, 11 (3), 337-344. https://doi.org/10.1016/j.jsams.2006.11.008

Markovic, G., \& Jaric, S. (2007). Is vertical jump height a body size independent measure of muscle power? Journal of Sports Sciences, 25(12), 1355-1363. https://doi.org/10.1080/02640410601021713

Massuca, L., \& Fragoso, I. (2011). Study of Portuguese handball players of different playing status. A morphological and biosocial perspective. Biol Sport., 28(1), 37-44. https://doi.org/10.5604/935871

Moncef, C., Said, M., Olfa, N., \& Dagbaji, G., (2012). Influence of morphological characteristics on physical and physiological performances of tunisian elite male handball players. Asian Journal of Sports Medicine, 3(2), 74-80. DOI: $10.5812 /$ asjsm.34700

Nikolaidis, P. T. (2013). Body mass index and body fat percentage are associated with decreased physical fitness in adolescent and adult female volleyball players, J Res Med Sci., 18(1), 22-26.

Ostojic, S. M., Majic, S., \& Dikic, N. (2006). Profiling in basketball: physical and physiological characteristics of elite players. Journal of Strength and Conditioning Research, 20(4), 740-744. https://doi.org/10.5812/asjsm.34700

Özkan, A., Köklü, Y., Eyuboğlu, E., Akça, F., Koz, M., \& Ersöz, G. (2010). The determination of relationship between body composition, somatotype, anaerobic performance, leg and back strength in female volleyball players. Gazi Beden Eğitimi ve Spor Bilimleri Dergisi, 15(4), 23-34.

Palao, J. M., Manzanares, P., \& Valadés, D. (2014). Anthropometric, physical, and age differences by the player position and the performance level in volleyball. J. Hum. Kinet., 44, 223-236. https://doi.org/10.2478/hukin-2014-0128

Savaş, S., \& Uğraş, A. (2004). Effects of 8-week pre-season training program on some physical and physiological characteristics of collegiate male box, taekwondo and karate players. Gazi Üniv. Gazi Eğitim Fakültesi Dergisi: 24(3), 257-274. https://doi.org/10.12965/jer.150196

Sevim, Y. (2002). Antrenman Bilgisi. Ankara: Nobel Yayın Dağıtım.

Silvestre, R., West, C., Maresh, C. M., \& Kraemer, W. J. (2006). Body composition and physical performance in men's soccer: a study of a national collegiate athletic association division I team. J Strength Cond. 20(1), 177-183. https://doi.org/10.1519/R-17715.1

Şimşek, B., Ertan, H., Göktepe, A. S., \& Yazıcıoğlu, K. (2007). The effects of knee muscle strenght on jumping height in female volleyball pleyers. Egzersiz, l(1), 36-43. https://doi.org/10.15314/tsed.349484

Şimşek, B., Tuncel, F., Ertan, H., \& Göktepe, S. (2005). The evaluation of selected physical fitness parameters at different league categories in female voleyball players. Gazi Üniv. BESBD, 10(3), 2-38. DOI:10.5277/abb130413 
Valleser, C. W. M., Bersola, K. A. R., Mallari, M. F. T., Papa, E. L. V., Diaz, F. C. B., Maghanoy, M. L. A., \& Lariosa, C. J. D. (2018). Anthropometric profile of elite women's volleyball players in the Philippines. Turk J Kin, 4(2), 53-57. DOI: $10.31459 /$ turkjkin.417481

Vuleta, D., Jerak, T., \& Sporiš, G. (2016). Difference in jumping ability and body composition in competitive volleyball setters. Acta Kinesiologica, 10(1), 45-48. https://doi.org/10.31459/turkjkin.417481

\section{Copyrights}

Copyright for this article is retained by the author(s), with first publication rights granted to the journal.

This is an open-access article distributed under the terms and conditions of the Creative Commons Attribution license which permits unrestricted use, distribution, and reproduction in any medium, provided the original work is properly cited. 